\title{
4. Plagiarism and fabulism: Dishonesty in the newsroom
}

\section{ABSTRACI}

In New Zealand, various journalism ethics codes either specifically condemn news media plagiarism - the passing off by a reporter of another's work or part work as one's own - or demand standards of accuracy and honesty that would preclude its use. Obviously the codes also preclude fabulism - outright story invention. In regard to the two, ascribing blame for plagiarism is the more problematic. This is because the public nature of news and the press's imperative to background and disseminate invariably lead to shades of grey. There is no such ambiguity for fabulism. This article therefore concentrates on plagiarism, discussing fabulism only because the two sins are often confused, especially when some high-profile transgressors have been guilty of both. Because plagiarism's definitional boundaries can be blurred, this paper examines - in the context of print journalism - the complexity of the problem and the difficulties inherent in finding workable solutions. To do this, on the path toward a definitional understanding, if not absolute definition, it considers underlying legal and ethical frameworks, historical and cultural origins, and the temptations and grey areas thrown up by the internet. In response to anecdotal public relations industry concerns it also includes a brief discussion of the rights and wrongs of reproducing press release material in its entirety.

\section{ALAN SAMSON \\ Massey University}

\section{Introduction}

EWS MEDIA plagiarism is nothing new. As far back as 1938, a French
journalism charter (Richards, 2005) found it necessary to include: 'A
journalist worthy of the name does not commit any plagiarism' ( $\mathrm{p}$. 107). The charter, which began in 1918, also says reporters should be held 
responsible to their peers (Doland, 2003). It is known that the stealing of others' words to produce pirated versions of literary works goes back at least as far as Shakespeare: the first version of Hamlet sold by booksellers was a pirated copy, a shoddily written unauthorised rip-off (Hannis, 2004). Stealing copy, it seems, has always been with us, and human nature suggests that state of affairs is likely to continue. Recent cases to hit the news include New York Times fabulist and plagiarist Jayson Blair and, at home, New Zealand Herald plagiarist Renee Kiriona.

Johannesen (2002) describes how the ethical offence of plagiarism developed in the shift from oral expression to print: 'The development of print typography fostered the view of words as commodities and private property' (p. 236). It could be argued that unlike fabulism, plagiarism is a singularly 'victimless' crime - affecting readers only to the extent that they are misled over authorship and ownership. But it could also be argued that there is a fundamental issue of trust to be considered here that has considerable implications. If deceit becomes evident in one area of publication, why should not one expect it also to emerge in another? Indeed, why subsequently take an offending paper or reporter seriously? Today, newspaper plagiarism has become sufficiently a concern for the press in numerous countries, from Sri Lanka to Czechoslovakia, to explicitly ban the practice (Richards, 2005).

The fact that plagiarism practice appears to be timeless could be taken as an argument for recommending the status quo: trusting in the alertness of senior editorial staff, as well as in the reach of print watchdog the New Zealand Press Council, and broadcasting watchdog the Broadcasting Standards Authority. But recommendation for such a laissez faire approach is readily contradicted by, firstly, the prominence of several recent high-profile plagiarism cases that have damaged broader journalistic reputations and, secondly, an increasing recognition that new technologies have made the practice easy to accomplish.

Fabulism, of course, is a different beast. Although the two forms of transgression have in common a dishonest intent, and the deceptions have, in a few, well-publicised examples, overlapped, Plotz (2002) draws a sharp distinction between the two:

There is surprisingly little overlap between plagiarists and fabulists. The New Republic's fabulous fabulist [Stephen Glass] didn't plagiarise. Historian Joseph Ellis, who concocted a fake Vietnam War record 
for himself, seems to do rock-solid scholarship. Some pants-seat speculation why the two groups differ: plagiarism and fantasy stem from opposite psychopathologies. Essentially, fabulists can't find anything in the real world that equals their imagination. That's why they make things up, because what they invent is more interesting than what they see around them. Plagiarists, by contrast, find too much in the real world that equals their imagination. They steal because there is too much other writing around that tempts them-what they see around them is more interesting than what they write themselves. (p. 1)

It is beyond the scope of this paper to research or reach conclusions on the psychology behind the cheating. But Plotz points out that, no matter what plagiarists steal, they invariably fall back on clichéd excuses. Mallon (1989) describes how, before the computer age, plagiarists blamed their plagiarisms on confusions in their notebooks, claiming they had mixed up their own notes with passages recorded elsewhere. But these days, he says, they are more likely to claim they have mistaken electronic files of notes with their own writings.

This article explores the commonality of plagiarism practices, particularly in New Zealand; the codes of ethics and laws that preclude its ethical and legal practice; and issues in relation to the electronic milieu that provides lush breeding ground.

\section{Plagiarism cases: Abroad and at home}

The second paragraph of The New York Times's revised code of conduct (2003) reads:

For more than a century, men and women of The Times have jealously guarded the paper's integrity. Whatever else we contribute, our first duty is to make sure the integrity of The Times is not blemished during our stewardship. (p. 3)

Media watchers would not have been slow to recognise the irony of the 2003 timing of the revised work. That was the year the world of young reporter Jayson Blair came tumbling down with The Times's 7000-word admission of May 11 that it had published his numerous fabricated and plagiarised stories. Under the headline 'Correcting the Record', the newspaper's front page lead conceded (Hirst \& Patching, 2005):

86 PACIFIC JOURNALISM REVIEW 11 (2) 2005 
A staff reporter for the New York Times committed frequent acts of journalistic fraud while covering significant news events in recent months, an investigation by Times journalists has found. The widespread fabrication and plagiarism represent a profound betrayal of trust and a low point in the 152-year history of the newspaper. (p. 247)

The newspaper's code (2003) includes:

Staff members who plagiarize or who knowingly or recklessly provide false information for publication betray our fundamental pact with our readers. We will not tolerate such behavior. (p. 7)

Blair was an up-and-coming then 27-year-old African-American reporter who, the paper revealed, had habitually filed stories from places he never visited, quoted people he never talked to, described details he had never seen, and used details from photographs to create the impression he had been somewhere or seen someone, when he had not. He had also plagiarised, a sin that contributed to his downfall: when a young former Times colleague-Macerena Hernandez-wrote a story for the San Antonio Express-News about the last American soldier missing in action in Iraq, Blair had written a close copy and Hernandez had become convinced he had stolen from her (Hirst \& Patching, 2005).

The Blair case attracted international attention — and opprobrium — but it was far from the first case of such misrepresentation. The publicity surrounding his deceptions led to recollections of earlier plagiarisms and reminded us of earlier exposés (Plotz, 2002; Brown, 2004). Noted United States cases (Plotz, 2002) include National Public Radio's Nina Totenberg, who plagiarised a Washington Post story about American Speaker of the House Tip O'Neill when she was a young print reporter; the New York Times's Fox Butterfield who stole several paragraphs of a Boston Globe story-a story about plagiarism; and the New Republic 's Ruth Shalit, caught after having cut and paste others' material for five different stories.

Other high-profile American journalists have gone even further, simply making up their stories and quotes. Notable among these have been the New Republic's fabulist Stephen Glass (who between 1995 and 1998 backed up numerous fictions with fake websites and phone numbers) and the Washington Post's Janet Cooke (who won the Pulitzer Prize for her 1980 story about 
an invented eight-year-old heroin addict). Extending the net to copyists in other modes of writing would bring in author Alex Hayley, who settled out of court with a writer he stole from for his epic Roots; novelist Jacob Epstein, who stole 53 passages from a Martin Amis novel; Martin Luther King Jr., who stole much of his dissertation; and former United States senator Joe Biden, who was forced out of the 1988 presidential campaign for what has been described as serial plagiarism.

The issue of news media plagiarism flared in New Zealand in 2004 when young New Zealand Herald reporter Renee Kiriona, after an unforthcoming interview with rugby league star Tawera Nikau, looked to the internet for information about him. Finding a profile written by a Waikato Times writer, she added a few pars of her own for the top, then submitted it as her own. She subsequently re-interviewed Nikau, sending in a second version of her story, though this still contained some Waikato Times detail. Unfortunately, she neglected to tell her editor who, with two story versions on her desk, combined the copy. Writing about the Kiriona case in the New Zealand Listener, media commentator Russell Brown (2004) named some earlier sinners, including some of New Zealand's most well-known journalism practitioners. He cites Shenagh Gleeson - the author of a Herald backgrounder about the Kiriona affair - describing how in her own early reporting career on the Waikato Times she and other reporters routinely lifted from originals they were asked to match.

In a 1977 Press Council case cited by Brown, former Metro magazine editor Warwick Roger, then a reporter for The Dominion, was censured for taking quotes recorded by film-maker Richard Turner for a documentary on the Black Power gang, and using them without permission in two major crime stories. In those days, unlike today, the Press Council relied entirely for guidance on its judgments on a system of case law (Elsaka, 2002). The council said Roger had agreed 'he and/or The Dominion failed to make adequate acknowledgement that a very large part of those two articles (including all the direct quotations) consisted of the work of Richard Turner' (Press Council, 1977). It upheld complaints that The Dominion had appropriated the material (Complaint 89) and that the material had been used incorrectly (Complaint 90), but dismissed a further complaint that the material had been sensational and titillating (Complaint 91). The judgment included: 'He had not thought it necessary to approach the publishers of [a magazine that had ear- 
lier carried the material] to make sure they did not have an interest in the material' (p. 12). Roger has also been upbraided by AdMedia magazine for, in a North \& South story, using paragraphs as his own from Sebastian Junger's novel The Perfect Storm (Brown, 2004).

Perhaps the most famous case of outright invention to occur in New Zealand was a report of the Soviet-Afghanistan conflict in a 1985 issue of the then New Zealand Times. The story, complete with graphic photographs, was attributed to occasional correspondent Greg Hyam, purportedly reporting under fire from Russians fighting to subdue Afghan rebels. On February 10, the paper's editor Bob Fox ran a front-page apology in which he said Hyam had been on holiday in the South Island at the time he claimed to be in Afghanistan. Hyam had admitted the hoax after readers pointed out a similarity between his pictures and those published from other wars, such as Vietnam and Lebanon. He had subsequently confessed that the article was entirely a fabrication, that he had never been in Afghanistan, and that he had taken all his photographs from other publications (Afghan hoax, 1985).

Plagiarism most recently came before the Press Council in 2004 (Case 977), in a case in which it upheld a complaint about a Southland Times reporter lifting quotes from Queenstown paper Mountain Scene-but only because there was no larger attribution. The reporter had used the quotes verbatim after being declined an interview with Queenstown Airport Corporation chairman John Davies. Davies had apparently referred her to the article in question, saying it was word perfect (Press Council, 2005). The council ruled against the Southland Times on two counts: that by not attributing the source of quotes it left readers with a false impression that the material had been directly collated by its own staff; and for the story's claim that there had been an interview with Davies. Some might debate a ruling that seems to rule out a reporter's confirming of, and receiving permission, before reproducing direct quotes that have appeared in another publication. But the council clears the paper of plagiarism by way of the main contents originating with Mountain Scene. In a separate commentary (Press Council, 2005) it says:

If the Southland Times story had been correctly attributed there would have been no basis for the complaint. Because the piece failed to credit the source or make any attempt at proper attribution, the Press Council had no recourse but to rule that the "paper had breached acceptable journalism standards'. (p. 9) 
It is impossible to know just how extensive plagiarism has been or is in New Zealand, though it is accepted, to one degree or other, as being common. Anecdotally, numerous named examples have occurred that have never been referred to an ethics body, or to have been written about, some of them deemed serious enough to lead to sackings. And most senior journalists spoken to recall at some time in their careers being plagiarised.

\section{New Zealand law and ethical codes}

Snapper (1999) argues that the burgeoning extent of web-based publications lessens the importance of piracy, but heightens the need for protections against plagiarism. His argument is based on the dramatically reducing costs of publication in the electronic media. But the observation gives no assistance or clue as to how to clamp down on the practice of plagiarism.

The law, common or statutory, has historically not been seen as a useful tool for deterring news media plagiarism. Copying another's work breaches the Copyright Act 1994, but the law requires there to have been, at the least, a significant copying for there to have been an offence. Legal commentary makes it clear that an obvious breach would be made by any newspaper that published verbatim an article lifted without permission from another newspaper. The statute defines 'copying' as reproducing a work in a material form, but also says that copying a substantial part of a work is as much a breach as copying the whole. That means that it is a breach to lift parts of another person's work, though the Act requires that the parts lifted must be 'substantial' - and legal judgments have found that that word does not refer solely to quantity but also to quality (Burrows \& Cheer, 2005). 'The fundamental question is whether the essence of the copyright work has been taken. Thus, the copying of a quantitatively small part of someone else's work can be a breach of copyright' (p. 161). It should be added that the copyright lies not with the news per se, but with its presentation. So, legally, if someone substantially rewrites another's news story, they are unlikely to be breaking the law.

Law also prohibits the 'passing off' of one person's intellectual property wares as those of another. Burrows and Cheer (2005), however, see such law — in respect of the news media — as only applying to issues like similarity of title, use of a created story character, popular author pseudonyms, and character merchandising. Key elements of common law judgment on these 
issues require there to have been a misrepresentation in trade likely to have adversely affected another's goodwill or business. The Fair Trading Act 1986 also prohibits misleading or deceptive conduct in trade.

Where plagiarism can be and has been tested in New Zealand, is in the arena of ethics, and the judgments of the various ethics-ruling bodies that act as watchdogs to everyday journalism practice. The code set up by former newspaper group owner Independent Newspapers Ltd - and adopted, after the purchase of its New Zealand newspaper holdings, by individual newspapers of purchaser Fairfax New Zealand-requires editorial staff to 'value originality in journalism and take every reasonable precaution to avoid plagiarism' (Independent Newspapers Ltd., 1997, p. 1). Neither the New Zealand Press Council's Statement of Principles (NZ Press Council, 1999) nor the journalist union's code of ethics (NZ Amalgamated Engineering, Printing \& Manufacturing Union, 1988) explicitly ban plagiarism. But they both require of journalists, scrupulous honesty. Similarly, broadcasting codes of practice for radio and television (Broadcasting Standards Authority, 2004) require of news practitioners, as well as accuracy, a constant review of standards of integrity and reliability of news sources.

Unlike the broadcasting authority, which is a statutory body with the power to fine or put a station off air, the Press Council's authority is entirely selfregulatory. Its power lies in the agreement of newspapers and magazines to be so regulated; its effective punishment relies on a transgressor's agreement to substantially and prominently run a council's judgment against it. The council's statement of 13 'principles', rather than a detailed list of specific transgressions, is intended to allow for flexibility in decision-making. But the looseness has attracted criticism for what some perceive as a complaintsdriven focus (Tully \& Elsaka, 2002). Plagiarism is not identified as a sin, though is able to be - and has been — ruled against under a larger prescript. Tully and Elsaka say (p. 145):

In our view the Council's statement of principles is a very disappointing document that reflects its complaints-driven focus. The preamble certainly emphasises the public interest in maintaining freedom of expression, but the 12 clauses (a 13th clause merely sets the requirement for editors to publish the substance of upheld adjudications) are not set in the context of fundamental ethical principles such as truth-telling, fairness and independence ... the 12 points developed by the print in- 
dustry's watchdog as a guideline to ethical practice include mundane matters, such as the handling of letters to the editor, headlines and captions but nothing on such important issues as conflicts of interest and chequebook journalism.

Nevertheless, the largely common-law nature of the council's judgments has allowed for rulings on plagiarism and for some understanding of the parameters of its definition. And regardless of any lack of precise written guiding detail, it is hard to imagine how any working journalist could not be aware that plagiarism is considered a sin by the news media industry.

Whether the codes and principles have a guiding effect on journalistic practice is open to question. McGregor (1997) says that in 20 years of newsroom experience, she could not recall codes being referred to in the many instances of moral choice that surrounded difficult stories and issues. Instead, what could be called 'intuitive morality' prevailed. She refers to a comment by journalism lecturer Jim Tully that journalists are mainly guided by 'newsroom learning', anecdotal knowledge of past behaviour (p. 137). The source of journalistic understanding of wrongdoing might not lie with the codes, but the understanding itself can be taken as widespread.

\section{The internet factor}

The internet has brought an unparalleled freedom of access to information. Richards (2005) refers to it also as providing a vast range of sources to plagiarise:

The ongoing dilemma posed by the internet is that plagiarism has become easier, inasmuch as there is a virtually unlimited range of sources to plagiarise, and plagiarism of much internet material is extremely difficult to detect. (p. 107)

Richards also makes the point that ethically, the objections to plagiarism are the same whether the plagiarised material comes from electronic or non-electronic sources:

Even if it becomes a more extensive problem, the ethical position will remain constant: plagiarism by journalists always has been, and always will be, unacceptable. While it is possible that, under pressure from the sheer amount of material easily accessible via the internet, the under-

92 PACIFIC JOURNALISM REVIEW 11 (2) 2005 
standing of what constitutes plagiarism might fray at the edges, it seems that the more immediate problem will be how to detect it. (p. 107)

It is widely accepted, however, that the internet is having a significant effect on mainstream journalism, both in writing styles and, significantly, the easy backgrounding of information for inclusion in stories. Owen (2003) says the new technology has been instrumental in a 'shift in popular tastes toward more fast-paced, engaging, less serious media fare, and an ability to meet the dynamic lifestyle and scheduling needs of an increasingly diverse public (p. 2). Young (2001) says:

The first decade of the mainstream internet has been accompanied by a utopian rhetoric of freedom. The net's apparent decentralised nature and lack of control hierarchy lead many to suggest that freedom and openness are intrinsic components of the new media domain (p. 11).

Using material from a source as broad and accessible as the internet clearly brings risks. Though not referring specifically to the internet, Cropp (1997) makes the sober point: "You have no way of being sure that the "borrowed" facts are correct, no matter how impeccable the source may appear' (p. 202). It can easily be inferred that the risk of inherited error on the net is exponentially larger than in the print medium. Cropp goes on to relate how two reporters once lifted information from a court story she had written about a defended court hearing they had not attended. Her report had contained a significant error inserted by a subeditor.

That the breadth and easy accessibility of the internet encourages word theft is difficult to gainsay. Some go so far as to argue that what is posted is fair game. Hirst and Patching (2005) cite educational consultant Dale Spender as arguing there is nothing wrong with searching the net for material, cutting and pasting it to come up with something new, and calling it one's own creation. Spender says cutting and pasting is the modus operandi of the internet and it is only 'print-primed professionals' who consider this an offence. She goes on to say that by continuing to apply 'the old rules', people fail to recognise that the medium has changed from print to digital.

So instead of declaring that the sky has fallen in, it might be more helpful for professional educators to do some thinking, for the internet is 
here to stay and yesterday's plagiarism is today's way of earning a living. (p. 266)

Hirst and Patching (2005), however, echo mainstream industry belief - and the Press Council - when they say of the practice, 'as she rightly pointed out, cutting and pasting is the modus operandi of the internet, but without suitable attribution it is classic plagiarism' (p. 266). What is clear is that, as plagiarism continues to rear its head in New Zealand journalism, so too do the challenges - in an electronic age — of dealing with it. The Press Council (2005) highlights the ease of transgression by observing that with electronic cutting and pasting, it can even be inadvertent:

It is easy to understand, if not approve, the modern-day journalist under pressure who might typically start a story by grabbing a couple of paragraphs of background material to slot into their own story without attribution. Journalists know that to present someone's work as their own is ethically wrong but somehow the practice of cutting and pasting electronically in this way seems to escape some people's ethics alarm bells. (p. 10)

Few Western observers would dispute that the open culture of the internet is, on balance, beneficial. Concerns, however, remain when ease of internet access translates into easy plagiarism pickings or, even more seriously, when the lifting becomes so commonplace it is not viewed as ethically wrong.

\section{Plagiarism as culturally variable}

Plagiarism as a concept is rooted in Euro-American print traditions. Johannesen (2002) says the tradition is based on beliefs in both individual originality and capitalistic commodification of ideas. The concern for the ethicality/legality of plagiarism developed with a growing Western culture emphasis on writing and print, together with ideas of individual originality and on capitalism:

The development of print typography fostered the view of words as commodities and private property ... in contrast, other cultures may view words and ideas not as individually created, privately owned commodities, but as communal intellectual resources to be shared and adapted. Such is true for primarily oral cultures. (pp. 236-237) 
Johannesen refers to public speakers in ancient Greece and Rome believing that imitation and borrowing should be 'openly and proudly admitted rather than concealed or hidden' (p. 237). Ideas and subject matter were then considered common property. Similarly, during the Middle Ages, concepts of plagiarism, copyright and authorship did not exist. And today, extant primarily oral cultures still see the creative power of the word as central to their traditions, and therefore able to be shared. He singles out the African-American culture, with its folk-preaching tradition, as one where 'oratorical plagiarism' might be seen as natural, accepted and ethical.

Given their own strong oral traditions, questions might be asked about the attitude of Maori to plagiarism. No local research is known to have been done in this area.

\section{Public relations and press releases}

The direct reprinting of quotes and background material from press, communications and public relations releases - substantially in the form and quantum in which they have been presented - is clearly deemed acceptable by many journalists, though they are usually taught to use such releases as a springboard (Press Council, 2005).

PR practitioners often say they are bemused to see their work appear verbatim under a reporter's byline - but they are never surprised. Seeing the material published, of course, is to their benefit, so complaints are unlikely. (p. 11)

Johnston (2002) argues that the very action of sending a press release to news outlets is tantamount to an implied licence to use and adapt the material:

Journalists' names appear on news stories that emerge from press releases written by somebody else. Public relations students proudly report that their release was used verbatim in the local paper, a high prize for the student, and a common occurrence on those papers that suffer understaffing. Students learn at an early stage in their academic careers that material generated by public relations practitioners is successful if it is professionally plagiarised. Indeed, this extends to the general business environment where bureaucratic plagiarism is part of the fabric. (p. 3) 
Quotes supplied via such media are clearly intended for publication, but there is a line to be drawn between a blanket publication of a supplied 'story' and the selected use of supplied material to be used in conjunction with further research.

The council conclusion is that, in this instance, the sin of copying could be one of laziness rather than plagiarism. It is supported in this by Mencher (2003) who correctly reminds journalists that their role is to dig beyond surface facts provided to them, material he calls 'source-originated material'emanating from press releases, handouts and speeches. 'Verification, background checking, direct observation and enterprise reporting amplify and sometimes correct source-originated material' (p. 246).

\section{Towards a definition}

According to the Press Council (2005), the application of the term 'plagiarism' to the news media varies from application to academic studies. Academic understanding of the term is itself far from simple. Building on a common understanding of plagiarism as simply the stealing of another's words and ideas without clear acknowledgement of source, Biggs (1999) identifies the main components as being 'repetition'-simply copying from an unacknowledged source - and 'patching' — copying with joining phrases, from several sources (p. 2). But he and others also put into the category of plagiarism a range of grey area practices, such as paraphrasing and joining sources without proper referencing, synthesising academic arguments of others as one's own, and false referencing.

There are even more areas of grey in judging the work of journalists. Among a range of problematic situations is the relatively frequent practice of newspapers using press association copy without attribution; similar reprintings that correctly attribute NZPA (New Zealand Press Association) but drop extra source attributions such as Reuters; or that include brief internet or electronic library-sourced background material for which the origin may have been forgotten or is of multi-origin. In a discussion of the work of students, Johnston (2002) says, while overt plagiarism is unacceptable in every discipline, assessment for journalism studies can fall outside the bounds of traditional essays and exams. For the journalism student, the internet is not only a legitimate source of research, but also a crucial medium in his or her work due to its accessibility, range and timeliness. Encouraging the sharing 
of material, an organisation's web site is often its flagship, presented as a site of factual information.

Citing news releases, Johnston goes on to say that the fields of journalism and public relations include a range of idiosyncratic issues which may appear as paradoxes between industry practice and academic learning. The Press Council (2005) also argues for a necessary latitude in the judging of journalists' work. Drawing a distinction of uniqueness, it says:

With its emphasis on 'finding the news', the medium is clearly in a different category from literary, artistic or musical works. The Press Council acknowledges that news is news wherever it comes from, and is able to be used freely. Judgment turns on the scale and detailed wording of the suspect material. Nevertheless, it is accepted newspaper practice that when using direct quotes from another source, rather than obtaining them directly from the person quoted, a publication must attribute those quotes. The news media today regularly pull together a vast number of sources - wire services, syndicated articles from overseas newspapers, magazines to which clipping rights are owned, rival newspapers and the electronic media, as well as staff reporters-for a single story. (p. 9)

The comment is a clear acknowledgement of the news media's unique and often contentious need to seize the news from wherever it can, and to include concurrent and immediate backgrounding. But it also acknowledges the need for honesty in attributing sources.

\section{Conclusion}

The issue of how to deal with plagiarism in the news media is a difficult one. In the academic world, it is being confronted head-on by website advice like www.plagiarism.org and programs like Turnitin and iThenticate, the latter being programs that scan and compare hundreds of millions of pages of essays and exam papers posted on the internet. Cheaters are also caught by a simple Googling of words or paragraphs of submitted works. Where there is a hint of suspicion the latter technique in particular could easily be introduced into the newsroom, though busy subeditors faced with deadlines might quickly grow impatient of a policing role. And as a check, such systems are far from pervasive and foolproof. 
That there are grey areas peculiar to journalism has to be acknowledged. And the fact remains that the multiplication of possible sources makes news media plagiarism much simpler than before. Ultimately, any resolution to the problem has to begin with an acceptance that there is a problem (Press Council, 2005):

The only possible way to confront the dilemma is to start by recognising that the intrinsic dishonesty of plagiarism is the same whether from electronic or non-electronic sources, PR press releases or a book. As Dr Richards points out, it is possible that under pressure from the sheer amount of material accessible via the internet, the understanding of what constitutes plagiarism can 'fray at the edges'. That does not mean we should accept dishonesty, rather that there is a need for increased debate and consideration. (p. 11)

As electronic wizardry makes plagiarism easier, it seems sensible for the industry to heighten its sensitivity to it. The Press Council (2005) recommends a first step of reminding all journalists of their obligation to truth and honesty - along with a nudge that any sort or degree of plagiarism is unacceptable. But it falls short of explaining how this can be achieved. And its conclusion that, given the immensity of the internet, a bigger problem remains of detecting plagiarism in the first place, similarly begs further consideration.

The call for debate within the news media would, however, appear to be a necessary first step in confronting the issue. Common definitions referring to theft of words and ideas provide a broad parameter of concern. But what does 'fraying at the edges' mean? The lack of a precise definition in any of the ethical codes leaves room for misunderstandings. Further research would appear to be warranted into the extent or perceived extent of news media plagiarism, so far defined just by a few high profile cases. There ought also to be broad-based news media discussion of the ethics of the matter, as of all ethical dilemmas to face journalists, beyond the level of 'intuitive morality'. It would be helpful to all industry workers, if clear definitional parameters could be drawn.

This debate should be guided by a higher direction than individual editors: New Zealand's two dominant newspaper chains, Fairfax New Zealand and APN News and Media, as well as the Newspaper Publishers' Association of New Zealand (which could bring in the viewpoints of the independents), 
and the New Zealand Press Council, not to mention an academic input, could all play a useful role. Finally, should Turnitin and the like prove too cumbersome, it might be possible for the industry to develop its own electronic computer detection programmes. Whether such a measure would be practical, or helpful, should also be the subject of industry discussion.

\section{References}

Afghan hoax on 'NZ Times'. (1985, February 11). The Evening Post, p. 25.

Biggs, J. (1999). Teaching for quality learning at university. Philadelphia: Society for Research into Higher Educations and Open University Press.

Broadcasting Standards Authority. (2004). Radio code of broadcasting practice. Wellington.

Broadcasting Standards Authority. (2004). Free to air television code of broadcasting practice. Wellington.

Brown, R. (2004, August 21-27). Walk away, Renee. New Zealand Listener, pp. 52-53.

Burrows, J. and Cheer, U. (2005). Media law in New Zealand (5th ed.). South Melbourne: Oxford University Press.

Cropp, A. (1997). Digging deeper: A New Zealand guide to investigative reporting. Wellington: New Zealand JournalistsTraining Organisation.

Doland, A. (2003). French editor's woes cause little stir. (Retrieved September 21, 2005 ): w w w. ed itorand publis her.com/e and p/new s/ article display.jsp?vnu content $\mathrm{id}=1922189$

Elsaka, N. (2002). The development of print media codes of ethics in New Zealand. New Zealand Journalism Monographs, 2, 1-68.

Hannis, G.D. (2004, April 3-9). Pirate of the Rings. New Zealand Listener, p. 34-35. Hirst, M. and Patching, R. (2005). Journalism ethics: Arguments and cases. Melbourne: Oxford University Press.

Independent Newspapers Ltd. (1997). INL code of ethics. Wellington.

Johannesen, R.L. (2002). Ethics in human communication. (5th ed.). Illinois: Waveland Press.

Johnston, J. (2002). A critical perspective on current structures governing internet plagiarism: Challenges to public relations and journalism education. (Retrieved 18 June 2005): www.bond.edu.au/hss/communication/ANZCA/papers/ JJohnstonPaper.pdf

Mallon, T. (1989). Stolen words: Forays into the origins and ravages of plagiarism. New York: Ticknor \& Fields.

McGregor, J. (1997). Lies, white lies and communication ethics. In F. Sligo, S. Olsson and C. Wallace (Eds.), Perspectives in business communication (pp. 127-138). Palmerston North: Software Technology.

Mencher, M. (2003). News reporting and writing. (9th ed.). New York: McGraw Hill Higher Education. 
MEDIA ETHICS AND ACCOUNTABILITY

The New York Times. (2003). Ethical journalism: Code of conduct for the news and editorial departments. New York.

New Zealand Amalgamated Engineering, Printing and Manufacturing Union. (1988). EPMU code of ethics for journalists. Wellington.

New Zealand Press Council. (1977). The New Zealand Press Council 5th annual report. Wellington.

New Zealand Press Council. (1999). NZ Press Council statement of principles. Wellington.

New Zealand Press Council. (2005). 2004: The 32d Annual Report. Wellington.

Owen, D. (2003). New media and contemporary interpretations of freedom of the press. (Retrieved 19 June 2005): www.lsu.edu/reillycenter/owen.pdf

Plotz, D. (2002). The plagiarist: Why Stephen Ambrose is a vampire. (Retrieved June 18, 2005): http://slate.msn.com/?id=2060618

Richards, I. (2005). Quagmires and quandaries: Exploring journalism ethics. Sydney: UNSW Press.

Snapper, J. W. (1999). On the web, plagiarism matters more than copyright piracy. Ethics and Information Technology, 1, 127-136.

Tully, J., \& Elsaka, N. (2002). Ethical codes and credibility: The challenge to industry. In J. McGregor \& M. Comrie (Eds.), What's News? Reclaiming journalism in New Zealand (pp. 142-152). Palmerston North: Dunmore Press.

Young, S. (2001). What's the big idea? Production, consumption and internet regulatory discourse. Media International Australia, 101, 9-19.

Alan Samson is a Lecturer in Journalism at Massey University, Wellington, New Zealand. Formerly a working journalist for 25 years, most recently at The Dominion newspaper, he is a sitting member of the New Zealand Press Council.

a.m.samson@massey.ac.nz

100 PACIFIC JOURNALISM REVIEW 11 (2) 2005 
Copyright of Pacific Journalism Review is the property of Auckland University of Technology and its content may not be copied or emailed to multiple sites or posted to a listserv without the copyright holder's express written permission. However, users may print, download, or email articles for individual use.

http://Mww.aut.ac.nz/depts/commstud/journ/pjrsubs.shtml 